\title{
ASSOCIATION BETWEEN PARENTING AND MALNUTRITION IN CHILDREN UNDER FIVE IN DILI, TIMOR LESTE
}

\author{
Adriana Fonseca da Silva, Stefanus P. Manongga, Frans Umbu Datta
}

Masters Program of Public Health, Universitas Nusa Cendana, Kupang

\begin{abstract}
Background: Malnutrition is one of the major causes of death for children, contributing to more than a third of child mortality globally. Childhood malnutrition remains common in Timor Leste. The World Health Organization reported that inappropriate feeding in children is responsible for one-third of the cases of malnutrition. This study aimed to examine the association between parenting and malnutrition in children under five in Dili, Timor Leste.

Subjects and Method: This was a case control study conducted at Sentru Saude Komunitaria Comoro and Sentru Saude Komunitaria Becora health centers, Municipio Dili, Timor Leste. A total of 162 of children under five years were selected for this study. The dependent variable was malnutrition. The independent variable was parenting in feeding and health. The malnutrition data was measured by stature meter and scale. The other data were measured by questionnaire. The data were analyzed by a multiple logistic regression.

Results: The risk of malnutrition decreased with good parenting in feeding ( $\mathrm{OR}=0.03$; $95 \% \mathrm{CI}=0.00$ to $0.18 ; \mathrm{p}<0.001)$ and good health parenting $(\mathrm{OR}=0.04 ; 95 \% \mathrm{CI}=0.00$ to $0.83 ; \mathrm{p}=0.038)$ at Sentru Saude Komunitaria Comoro. The risk of malnutrition decreased with good parenting in feeding $(\mathrm{OR}=0.11 ; 95 \% \mathrm{CI}=0.05$ to $0.18 ; \mathrm{p}<0.001)$ and good health parenting $(\mathrm{OR}<0.01 ; 95 \% \mathrm{CI}=0.00$ to $0.05 ; \mathrm{p}<0.001)$ at Sentru Saude Komunitaria Becora.

Conclusion: The risk of malnutrition is associated with parenting in feeding and health at Sentru Saude Komunitaria Comoro and at Sentru Saude Komunitaria Becora.

Keywords: malnutrition, parenting, feeding, health parenting.

Correspondence:

Adriana Fonseca da Silva. Masters Program in Public Health, Universitas Nusa Cendana, Kupang, East Nusa Tenggara. Email: fonsecaadriana72@yahoo.com. Mobile: o81266821015.
\end{abstract}

The $6^{\text {th }}$ International Conference on Public Health Best Western Premier Hotel, Solo, Indonesia, October 23-24, 2019 | 75 